\title{
SINTESIS DAN KARAKTERISASI CROSSLINK KITOSAN DENGAN TRIPOLIFOSFAT pH 3
}

\author{
Mardiyah Kurniasih $^{1)}$, Nurul Hidayat Aprilita ${ }^{2)}$, Indriana Kartini ${ }^{2)}$ \\ 1) Program Studi Kimia, Jurusan MIPA, Fakultas Sains dan Teknik UNSOED \\ 2) Jurusan Kimia, Fakultas MIPA, Universitas Gadjah Mada
}

\begin{abstract}
Chitosan is polycationic in acidic media and can interact with negatively charged species such as tripolyphosphate (TPP), which is a nontoxic crosslinking agent. The synthesis of TPP crosslinked chitosan was perfomed by reacting TPP solution (pH 3) with chitosan solution. The aim of this study was to prepared and characterize the crosslinked chitosan-tripolyphosphate samples. Characterization included determination of water and ash degree, moreover crosslinked chitosan-tripolyphosphate powder characterize with FTIR and XRD spectroscopy. The result showed that process efficiency of crosslinked chitosan-tripolyphosphate was $88.49 \%$, with degree of water and ash were 25.70 and $16.72 \%$, respectively.
\end{abstract}

Keywords : chitosan, crosslinked chitosan-tripolyphosphate, characterization.

\section{PENDAHULUAN}

Kitosan berbasis nanopartikel saat ini menjadi topik yang sangat menarik. Kitosan nanopartikel dapat dibuat dengan beberapa metode meliputi crosslink dengan: ion-ion TPP (Mi et al., 1999a; $\mathrm{Mi}$ et al., 1999b; Bhumkar dan Pokharkar, 2006; Jayakumar et al., 2006), ethylene glycol diglycidyl ether, carboxymethyl dan glutaraldehyde (Sun et al., 2006), epiclorohydrin (Goncalves et al., 2005) dan glutaraldehyde (Goncalves et al., 2005; Adriano et al., 2005).

Glutaraldehyde dan ethylene glycol diglycidyl ether merupakan agen crosslink yang sangat baik tetapi tidak disukai karena toksisitasnya. Kitosan yang bersifat polikationik dalam media asam dapat bereaksi dengan muatan negatif seperti TPP menghasilkan nanopartikel crosslink kitosan yang biocompatible (Bhumkar dan Pokharkar, 2006).

Kitosan polikationik dapat berinteraksi dengan ion pembawa (counterion) yang multivalensi seperti TPP membentuk kitosan-TPP melalui ikatan intermolekul dan intramolekul dengan reaksi ionik. Reaksi ionik kitosan dalam larutan TPP ada dua yaitu deprotonasi dan crosslink ionik, di mana keduanya dipengaruhi oleh $\mathrm{pH}$ larutan TPP yang digunakan (Bhumkar dan Pokharkar, 2006; Mi et al., 1999a; Mi et al., 1999b). Crosslink ionik terjadi ketika larutan TPP yang digunakan dalam sintesis derivat kitosan-TPP dalam kondisi asam. Bentuk crosslink ionik disajikan dalam Gambar 1.

Crosslink Kitosan-TPP yang dibuat dari larutan TPP dalam kondisi asam memiliki densitas yang lebih besar daripada kitosan-TPP yang dibuat dengan larutan TPP kondisi basa, yang ditunjukkan dengan lebih banyaknya ion TPP yang terikat. Kemampuan menggelembung (swelling) dari kitosanTPP tergantung dari densitas crosslink. Menurut Jayakumar et al. (2006) kitosanTPP dengan densitas kecil dalam $\mathrm{pH}$ 1,4 akan perlahan menggelembung dan akhirnya larut dalam 3 hari, sedangkan crosslink dengan densitas tinggi tidak akan larut dalam waktu yang sama. Hal ini karena banyaknya jumlah crosslink yang menutupi hidrofilik asam amino 
pada kitosan-TPP. Berdasarkan uraianuraian tersebut maka dilakukan penelitian sintesis crosslink kitosan-TPP dengan menggunakan larutan TPP $\mathrm{pH} 3$ dan karakterisasinya.

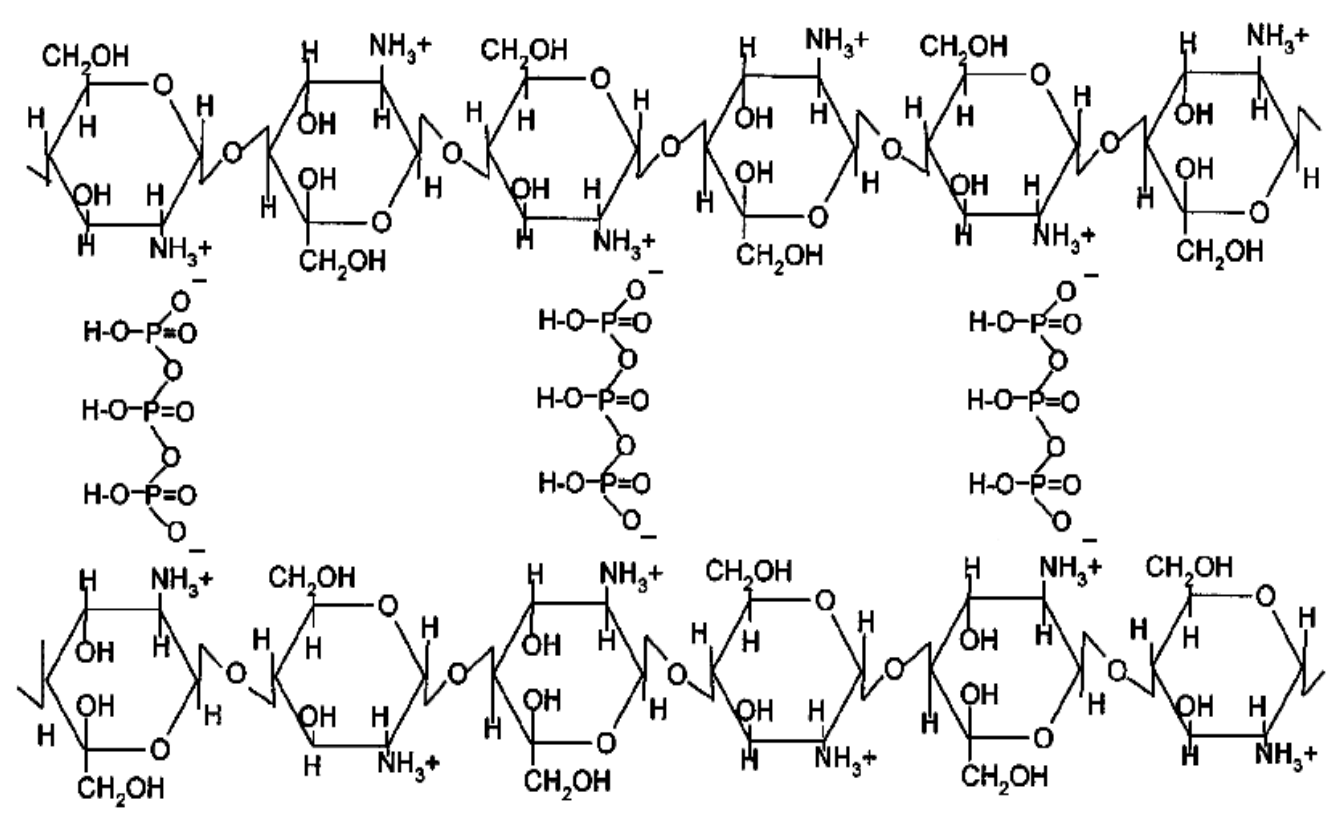

Gambar 1. Bentuk crosslink ionik dalam derivat kitosan-TPP ( Mi et al., 1999b)

\section{METODE PENELITIAN}

\section{Bahan dan Alat}

Bahan-bahan yang digunakan dalam penelitian ini adalah: kitosan, STTP $\left(\mathrm{Na}_{5} \mathrm{P}_{3} \mathrm{O}_{10}\right)$, akuades, akuabides dan air bebas mineral, sedangkan alatalat yang digunakan meliputi: $\mathrm{pH}$ meter model HM-5B, kompor listrik, kurs porselin, oven, timbangan analitik Mettler AE200 dan penyaring Bucher.

\section{Sintesis crosslink kitosan-TPP}

Sintesis crosslink kitosan-TPP mengacu pada Mi et al. (1999b). Kitosan dilarutkan dalam asam asetat kemudian ditambah larutan TPP $\mathrm{pH} 3$, disertai pengadukan. Endapan yang terbentuk kemudian disaring dengan penyaring Bucher dan dicuci dengan air bebas mineral berulang-ulang. Endapan kitosan-TPP yang diperoleh dikeringkan pada $40{ }^{\circ} \mathrm{C}$.

\section{Karakterisasi crosslink kitosan-TPP}

Karakterisasi crosslink kitosanTPP dilakukan dengan analisis Fourier
Transform Infra-Red Spectrophotometer (FTIR), X-Ray Diffractometer (difraksi sinar-X), penentuan kadar air, abu, protein dan lemak dari derivat kitosanTPP yang kemudian dibandingkan dengan raw material (kitosan) serta penentuan kadar fosfor $(\mathrm{P})$ dalam derivat kitosan-TPP.

Kadar air ditentukan dengan mengoven dan mengeringkan sampel pada suhu $100-105{ }^{\circ} \mathrm{C}$ selama 3 jam. Sampel kemudian didinginkan dalam desikator dan ditimbang.

Kadar abu ditentukan dengan memijarkan sampel pada cawan kosong dalam tanur suhu $600-650{ }^{\circ} \mathrm{C}$ sampai sampel bebas dari karbon yang ditunjukkan dengan warna sampel keabuabuan sampai putih. Sampel kemudian didinginkan semalam dalam desikator dan ditimbang.

Kadar fosfat (P) ditentukan secara kolorimetri dengan pereaksi vanadatmolibdat yang mengacu pada SNI 008692-A. Sampel padatan crosslink kitosanTPP didestruksi dengan asam nitrat 
pekat. Larutan sampel diambil dan dimasukkan dalam labu takar, ditambahkan akuades dan pereaksi vanadat-molibdat lalu diencerkan sampai tanda batas. Larutan didiamkan selama 15 menit dan diukur absorbansinya pada panjang gelombang optimum. Kadar P dalam sampel diketahui dengan ekstrapolasi absorbansi sampel pada kurva standar.

\section{HASIL DAN PEMBAHASAN Sintesis crosslink kitosan-TPP}

Kitosan dengan $\mathrm{pK}_{\mathrm{a}}$ 6,3 merupakan polikationik yang ketika dilarutkan dalam asam akan memberikan ion $-\mathrm{NH}_{3}{ }^{+}$. STPP ketika dilarutkan dalam air akan memberikan ion hidroksil dan ion TPP. Interaksi antara polikationik kitosan dengan ion TPP akan menghasilkan komplek polikationik-mulivalent anion, yaitu crosslink kitosan-TPP. Crosslink kitosan tergantung dari ketersediaan situs kation dan banyaknya situs negatif. Oleh karena itu, pH larutan TPP sangat berpengaruh dalam sintesis derivat kitosan-TPP dimana $\mathrm{pH}$ larutan TPP ini akan menentukan jenis crosslink yang terjadi. Berdasarkan parameter tersebut dalam penelitian ini dibuat crosslink kitosan-TPP dengan menggunakan larutan TPP $\mathrm{pH} 3$.

Crosslink kitosan-TPP akan terbentuk secara spontan ketika larutan TPP ditambahkan ke dalam larutan kitosan. Endapan kitosan-TPP yang diperoleh dicuci dengan air bebas mineral secara berulang untuk menghilangkan sisa ion TPP yang tidak bereaksi. Endapan yang diperoleh setelah tidak ada sisa ion TPP kemudian dikeringkan dalam oven dengan temperatur yang tidak terlalu tinggi untuk menghindari rusaknya rantai polimer.

Kitosan adalah polibasa lemah dan ketika $\mathrm{pH}$ larutan turun, ionisasi amina pada kitosan akan meningkat. Oleh karena itu, mikropartikel kitosan-TPP yang dibuat pada larutan TPP asam keseluruhan didominasi oleh crosslink ionik (Mi et al., 1999a; Mi et al., 1999b; Bhumkar dan Pokharkar, 2006).

Berdasarkan hasil penelitian sintesis crosslink kitosan-TPP menggunakan larutan TPP dengan $\mathrm{pH} 3$ diperoleh rendemen sebesar $88,49 \%$.

\section{Karakterisasi crosslink kitosan-TPP}

Terbentuknya crosslink kitosanTPP dapat diketahui dari serapan IR padatan hasil sintesis. Spektra IR dari crosslink kitosan-TPP (Gambar 2) menunjukkan pita serapan pada bilangan gelombang 3425-3449 $\mathrm{cm}^{-1}$ yang menunjukkan tumpang tindih serapan vibrasi rentangan gugus $-\mathrm{OH}$ dan $\mathrm{N}-\mathrm{H}$. Pita serapan pada bilangan gelombang 2927-2947 $\mathrm{cm}^{-1}$ menunjukkan vibrasi rentangan $\mathrm{C}-\mathrm{H}$ dari $-\mathrm{CH}_{2}-$ alifatik. Pita serapan pada vibrasi bengkokan $\mathrm{N}-\mathrm{H}$ dari amida primer muncul pada bilangan gelombang 1627-1636 $\mathrm{cm}^{-1}$ sedang pita serapan pada bilangan gelombang 1543$1534 \mathrm{~cm}^{-1}$ muncul karena adanya interaksi antara ion amonium dengan ion fosfat (Bhumkar dan Pokharkar, 2006). Serapan bengkokan $-\mathrm{CH}_{3}$ pada bilangan gelombang 1380,9 $\mathrm{cm}^{-1}$ masih muncul. Hal ini menunjukkan kalau masih ada gugus asetil pada kitosan-TPP karena kitosan yang digunakan tidak terdeasetilasi sempurna. Rentangan $\mathrm{C}-\mathrm{O}$ teridentifikasi di bilangan gelombang $1087-1096 \mathrm{~cm}^{-1}$. Pada spektra IR padatan hasil crosslink kitosan-TPP muncul rentangan dari jembatan oksigen pada bilangan gelombang $1022-1026 \mathrm{~cm}^{-1}$ yang kemungkinan merupakan vibrasi rentangan $\mathrm{P}-\mathrm{O}$. 


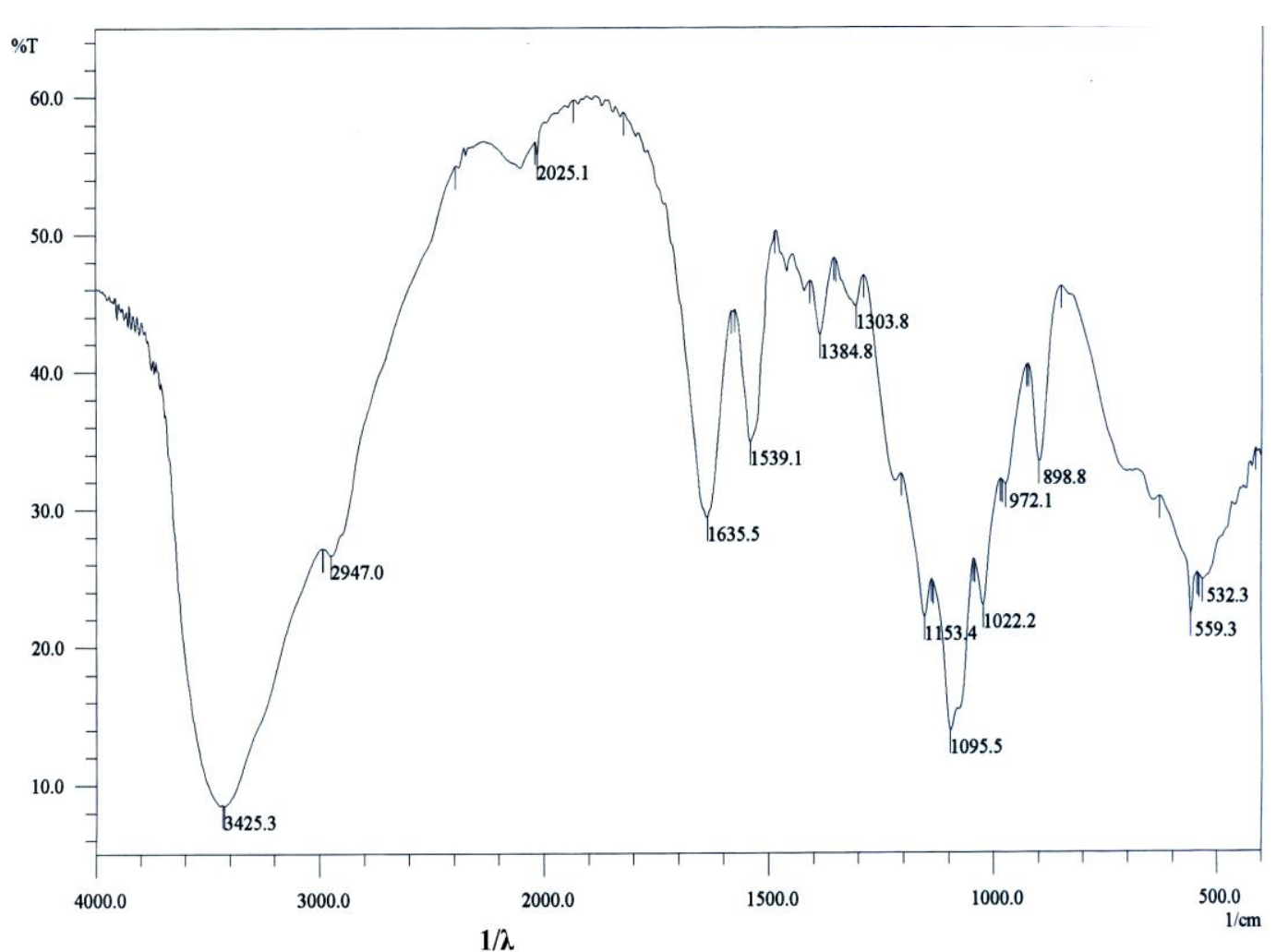

Gambar 2. Spektra IR crosslink kitosan-TPP

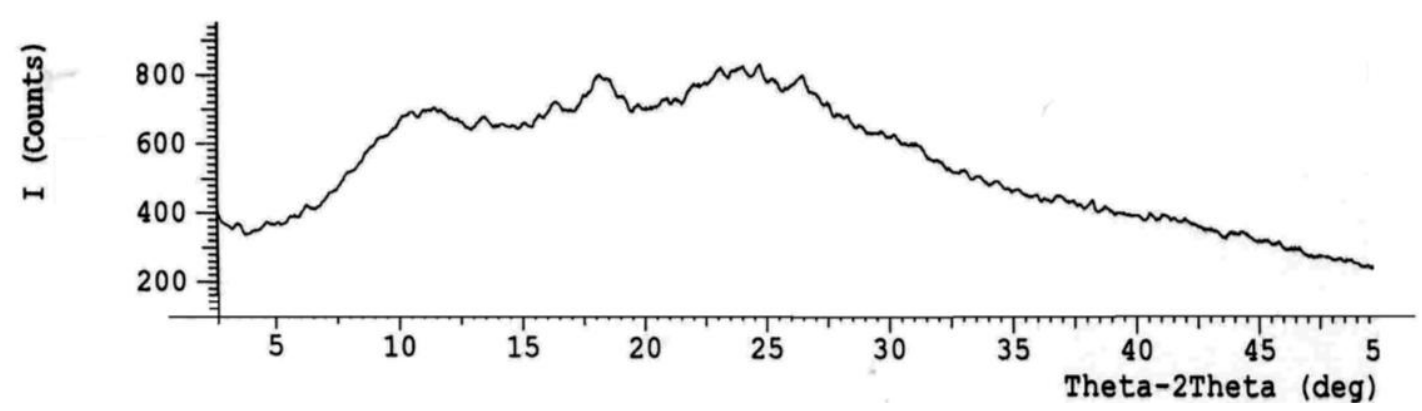

Gambar 3. Difraktogram crosslink kitosan-TPP

Karakterisasi crosslink kitosan-TPP dengan difraksi sinar-X menghasilkan difraktogram yang tersaji dalam Gambar 3. Tidak adanya puncak pada difraktogram crosslink kitosan-TPP mengindikasikan bahwa padatan bersifat amorf, hal ini serupa dengan yang dihasilkan Bhumkar dan Pokharkar (2006).

Kadar air dan abu crosslink kitosanTPP dibandingkan dengan raw material (kitosan) tersaji dalam Tabel 1. Kadar air kitosan hasil crosslink dengan larutan TPP lebih besar dari kitosan, hal ini disebabkan lebih banyaknya gugus - $\mathrm{OH}$ dalam padatan kitosan-TPP. Keberadaan fosfat (P) dalam crosslink kitosan-TPP mengakibatkan tingginya kadar abu dibanding pada kitosan.

Tabel 1. Kadar air dan abu crosslink kitosan-TPP dan kitosan

\begin{tabular}{lcc}
\hline \multirow{2}{*}{ Bahan } & \multicolumn{2}{c}{ kadar rata-rata } \\
& \multicolumn{2}{c}{$(\%)$} \\
\cline { 2 - 3 } & air & abu \\
\hline $\begin{array}{l}\text { crosslink kitosan- } \\
\text { TPP }\end{array}$ & 25,70 & 16,72 \\
kitosan & 19,34 & 0,17 \\
\hline
\end{tabular}

Penentuan kadar P dalam crosslink kitosan-TPP ditentukan dengan metode biru molibdat secara spektrofotometri. Sampel diperlakukan dengan asam 
perklorat untuk mengubah semua ion fosfat menjadi ortofosfat, kemudian sampel diperlakukan dengan pereaksi molibdat-vanadat sehingga ortofosfat yang ada di dalam sampel akan bereaksi dengan pereaksi-pereaksi tersebut dan membentuk kompleks asam vanadimolibdifosfat yang berwarna kuning orange. Intensitas warna dari senyawa kompleks tersebut dapat diukur dengan spektrofotometer pada panjang gelombang $400 \mathrm{~nm}$ (dari hasil optimasi panjang gelombang, yang tersaji pada Gambar 4) dan dibandingkan dengan standar fosfor yang telah diketahui konsentrasinya. Berdasarkan hasil perhitungan kadar fosfor dalam crosslink kitosan-TPP dengan menggunakan larutan TPP pH 3 adalah 12,64 \%.

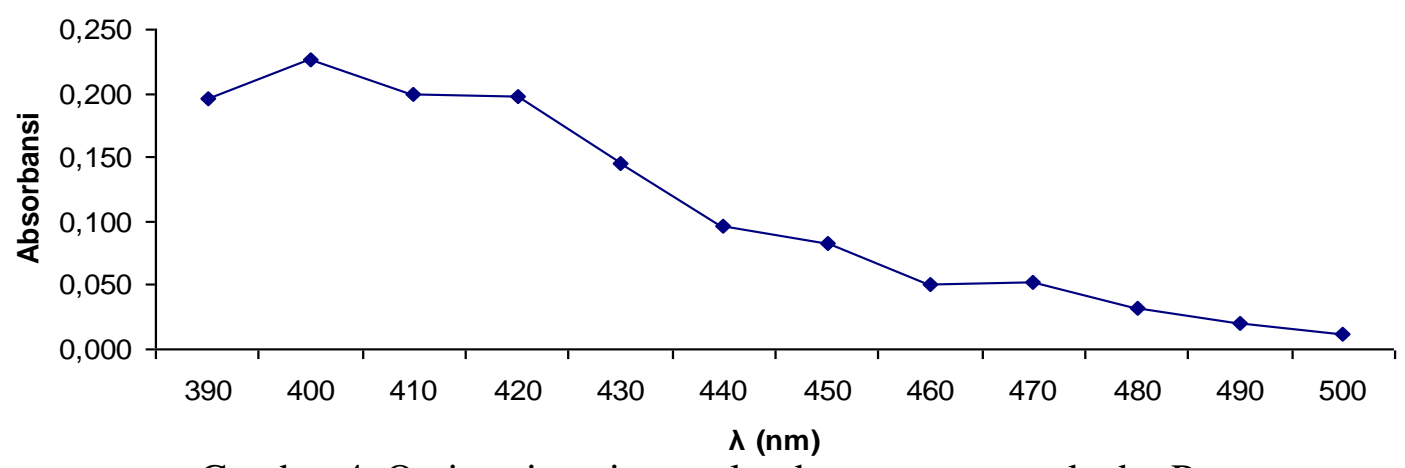

Gambar 4. Optimasi panjang gelombang penentuan kadar P

\section{KESIMPULAN DAN SARAN}

\section{Kesimpulan}

1. Sintesis crosslink kitosan-TPP menggunakan larutan TPP pada $\mathrm{pH}$ 3 memberikan rendemen $88,49 \%$.

2. Spektra IR padatan crosslink kitosan-TPP menunjukkan rentangan dari jembatan oksigen pada bilangan gelombang 1022$1026 \mathrm{~cm}^{-1}$ yang merupakan vibrasi rentangan $\mathrm{P}-\mathrm{O}$.

3. Pola difraksi sinar-X crosslink kitosan-TPP menunjukkan padatan bersifat amorf.

4. Berdasarkan hasil karakterisasi crosslink kitosan-TPP diperoleh kadar air sebesar 25,70 \% dan kadar abu $16,72 \%$.

\section{Saran}

Perlu dilakukan penelitian lebih lanjut mengenai aplikasi dari crosslink kitosan-TPP.

\section{DAFTAR PUSTAKA}

Adriano, W. S., E. H. C.Filho, J. A. Silva, R. L. C. Giordano, dan L.
R. B.Goncalves, 2005, Stabilization of Penicillin G Acylase By Immobilization On Glutaldehyde-Activated Chitosan, Braz. J. Chem. Eng., 22 (4), 529538.

Bhumkar, D. R. dan V. B.Pokharkar, 2006, Studies on Effect of $\mathrm{pH}$ on Cross-Linking of Chitosan With Sodium Tripolyphosphate: a technical note, AAPS PharmSciTech ,7 (2), Article 50.

Goncalves, V. L., M. C. M. Laranjeira, V. T Favere, dan R. C. Pedrosa, 2005, Effect of Crosslinking Agents on Chitosan Microspheres in Controlled Release of Diclofenac Sodium, Polimeros: Ciênc. Tecnol., 15, 6-12.

Jayakumar, R., R. L. Reis, dan J. F. Mano, 2006, Phosphorous Containing Chitosan Beads for Controlled Oral Drug Delivery, $J$. Bioact. Compat. Polym., 21, 327. 
Mi, F.L., S. S. Shyu, C.Y. Kuan, S.T. Lee, K.T. Lu, dan S.F. Jang, 1999a, Chitosan-Polyelectrolyte Complexation For The Preparation of Gel Beads and Controlled Release of Anticancer Drug. I. Effect of Phosphorous Polyelectrolyte Complex and Enzymatic Hydrolysis of Polymer, J. Appl. Polym. Sci., Vol. 74, 1868-1879.
Mi, F.L., S.S. Shyu, S.T. Lee, dan T.B. Wong, 1999b. Kinetic Study of Chitosan-Tripolyphosphate Complex Reaction and AcidResistive Properties of The Chitosan-Tripolyphosphate Gel Beads Prepared by In-Liquid Curing Method, J. Polym. Sci: Polym. Phys. 37, 1551-1564.

Sun, S., L. Wang, dan A. Wang, 2006, Adsorption Properties of Crosslinked CarboxymethylChitosan Resin With $\mathrm{Pb}(\mathrm{II})$ as Template Ions, J. Hazard. Mater. $B, 36,930-937$. 